\title{
DISTRIBUTION OF AFLATOXINS IN CORN FRACTIONS VISUALLY SEGREGATED FOR DEFECTS
}

\author{
Fabiana Segatti Piedade ${ }^{1}$; Homero Fonseca ${ }^{2 *}$; Eduardo Micotti da Gloria ${ }^{3}$; Maria Antonia Calori-Domingues ${ }^{3}$; \\ Sônia Maria Stefano Piedade ${ }^{4}$; Décio Barbin ${ }^{4}$
}

\begin{abstract}
${ }^{1}$ Ciência e Tecnologia de Alimentos, Escola Superior de Agricultura Luiz de Queiroz, Universidade de São Paulo, Piracicaba, SP, Brasil. ${ }^{2}$ Departamento da Produção Vegetal, Escola Superior de Agricultura Luiz de Queiroz, Universidade de São Paulo, Piracicaba, SP, Brasil; ${ }^{3}$ Departamento de Agroindústria, Alimentos e Nutrição, Escola Superior de Agricultura Luiz de Queiroz, Universidade de São Paulo, Piracicaba, SP, Brasil; ${ }^{4}$ Departamento de Ciências Exatas, Escola Superior de Agricultura Luiz de Queiroz, Universidade de São Paulo, Piracicaba, SP, Brasil.
\end{abstract}

Submitted: December 04, 2001; Returned to authors for corrections: July 01, 2002; Approved: September 24, 2002

\begin{abstract}
The aflatoxin distribution in corn fractions obtained after visual segregation for defects in 30 samples, known to be contaminated, was studied. Each sample was passed through a $5.0 \mathrm{~mm}$ round holes sieve, graded for defects and then segregated in sound kernels (regular kernels) and non-sound kernels (injured, germinated, fermented, moldy, heated, insect damaged, immature, broken, hollow, fermented up to $1 / 4$, discolored, extraneous materials, and injured by other causes), as defined by the Brazilian Official Grading rules for corn. The non-sound kernels showed the highest contamination levels in all samples. The contamination levels of non-sound kernels ( $20 \%$ of total weight) ranged from 23 to $1,365 \mu \mathrm{g} / \mathrm{kg}$ of aflatoxins $\left(\mathrm{B}_{1}, \mathrm{~B}_{2}, \mathrm{G}_{1}\right.$ and $\left.\mathrm{G}_{2}\right)$ and were higher than sound kernels $(\mathrm{p}<1 \%$ ) ranging from not detected (ND) to $126 \mu \mathrm{g} / \mathrm{kg}$ and in $87 \%$ of these the aflatoxin contents were lower than $20 \mu \mathrm{g} / \mathrm{kg}$. Statistically significant correlation indexes were found among the percentage of defective groups like fermented, heated and sprouted kernels or the total injured kernels, and the estimated contamination levels for the sound and non sound fractions. It was concluded that the non-sound kernels fraction, even being small in weight, has contributed with $84 \%$ of the estimated contamination of the samples. The segregation of the nonsound kernels would favor a reduction in the contamination of corn lots. The poorer quality corn types (types 3 and Bellow Standart) have predominated among samples of the experiment.
\end{abstract}

Key words: aflatoxins, corn, contamination distribution, visual segregation, fraction.

\section{INTRODUCTION}

Corn is a basic ingredient of human and animal feeding. Due to its nutritional composition it is a good substrate for fungi development that may cause nutritional losses and production of toxic substances known as mycotoxins (8).

Corn follows peanuts, as the most reported aflatoxins contaminated commodity (9). Several researches on aflatoxin contamination in corn were published in Brazil. Fonseca et al. $(5,6)$, in a two-year survey with samples taken from supermarkets in the State of São Paulo, reported the presence of aflatoxin in $4.7 \%$ of corn samples, with a maximum contamination level of $2,000 \mu \mathrm{g} / \mathrm{kg}$. Sabino et al. (11) also found that $10.4 \%$ of corn samples were contaminated. In a survey of 238 corn samples destined to poultry and swine feed, in Southern Brazil region (12), it was found that 28.5\% were positive for aflatoxin. Gloria et al. (7) analyzed in the State of São Paulo, 292 corn samples taken from truckloads in the arrival at a wet-milling plant and found that $33.6 \%$ of them were aflatoxin positive. Santúrio et al. (13), analyzed 1,263 samples of corn and 1,006 samples of corn based rations, coming from several Brazilian States, in a period of ten years.

\footnotetext{
* Corresponding author. Mailing address: Rua Dona Eugênia, 269 - 13416-218, Piracicaba, SP, Brasil. E-mail: hfonseca@merconet.com.br
} 
They found that 645 samples of corn and 468 samples of rations were positive for aflatoxins, with a maximum level of 14.4 and $5.1 \mu \mathrm{g} / \mathrm{kg}$, respectively.

The contamination of agricultural commodities with mycotoxins is not uniform and very often only a few highly contaminated kernels may be present in a lot. That is the reason for the high variation in mycotoxin determination in samples of the same lot, and this fact turns difficult the determination of the actual concentration of these mycotoxins in a lot.

Some literature data have showed that probably aflatoxin contamination is concentrated in specific corn kernel types. According to Christensen and Kaufmann (4), injured and broken kernels are more susceptible to fungal attack than whole kernels. Rambo et al. (10) have observed a higher incidence of Aspergillus flavus in injured kernels. Shotwell et al. (14) have studied the aflatoxin distribution in corn lots and observed that large pieces of corn broken kernels $(>4.5 \mathrm{~mm})$ and injured kernels were highly contaminated. Afterwards, Shotwell et al. (15) observed that discolored corn kernels, although apparently sound, also presented high aflatoxin contamination and Shotwell et al. (16) verified that corn fractions that presented insect damage, discoloration, injured and broken were more contaminated with aflatoxins.

On the other hand, aflatoxin contamination was found in whole and apparently sound kernels in 10 lots of aflatoxin contaminated corn (3).

The aim of this study was to verify the distribution of aflatoxin in fractions, obtained after the visual separation of contaminated corn samples in sound and non-sound kernels.

\section{MATERIALS AND METHODS}

\section{Sampling and sample treatment}

Thirty samples of aflatoxin-contaminated corn were drawn from truckloads at their arrival in a food industry in the State of São Paulo, Brazil.

Two samplings were made in two periods and 16 samples and 14, respectively, were collected. Each sample was composed of several incremental samples taken from different points of the load, according to the industry's scheme, and then gathered to form one sample of, approximately $3 \mathrm{~kg}$, considered representative of each load.

Every sample was previously screened for aflatoxins by the industry, according to the technique of the bright greenishyellow fluorescence (BGYF) and if found to be positive, the contamination was confirmed by an Immunoaffinity Column Method (Aflatest, Vicam).

The samples were homogenized and passed through a sieve with $5.0 \mathrm{~mm}$ round holes to discard smaller materials.

After obtaining a representative sample, a portion of $250 \mathrm{~g}$ was taken for grading, according to the Brazilian Official Grading rules for corn (Table 1).
Table 1. Tolerance levels of defects for corn grading in types, according to the Brazilian Official Grading rules for corn (1).

\begin{tabular}{|c|c|c|c|c|}
\hline \multirow[b]{3}{*}{ TYPES } & \multicolumn{4}{|c|}{ TOLERANCES } \\
\hline & \multirow[b]{2}{*}{$\begin{array}{c}\text { Moisture } \\
(\%)\end{array}$} & \multirow{2}{*}{$\begin{array}{c}\text { Extraneous } \\
\text { materials, } \\
\text { Impurities and } \\
\text { Fragments }(\%)\end{array}$} & \multicolumn{2}{|c|}{ Injured $(\%)$} \\
\hline & & & Total & $\begin{array}{l}\text { Maximum of } \\
\text { Fermented and } \\
\text { Sprouted }\end{array}$ \\
\hline 1 & 14.5 & 1.5 & 11 & 3 \\
\hline 2 & 14.5 & 2.0 & 18 & 6 \\
\hline 3 & 14.5 & 3.0 & 27 & 10 \\
\hline B.S.* & 14.5 & \multicolumn{3}{|c|}{ (To be specified in each case) } \\
\hline
\end{tabular}

*B.S. $=$ Bellow Standard.

Visual grading was then carried out according to the following defective kernels definitions:

Fermented, heated and sprouted kernels - kernels or pieces of kernels that have lost the coloration or color characteristics, by action of heat and humidity or fermentation in more than $1 / 4$ of the size of the kernel, and kernels or pieces of kernels that present visible germination.

Injured kernels - kernels or pieces of kernels, hollow, immature, attacked by insects, rodent or parasites, those fermented up to $1 / 4$ of the kernel size, as well as injured by different agents.

Impurities, foreign materials and broken - fragments of the plant, as well as kernels or fragments of kernels that pass through a sieve of circular sieves of $5.0 \mathrm{~mm}$ diameter holes and the kernels or seeds of other species, as well as the vegetal remainings and extraneous materials of any nature, respectively.

After grading the samples were identified and stored in a freezer at $-18^{\circ} \mathrm{C}$, in the laboratory, for further processing and analysis.

Each sample was passed through a $5.0 \mathrm{~mm}$ round holes sieves, and the fraction that passed through, plus the extraneous materials that did not pass through were taken out, remaining, in the sieve, only kernels. These kernels were then, hand picked selected and visually segregated in apparently sound kernels and kernels with some kind of injury or defect (non-sound kernels). The sound kernels were considered the regular kernels and the non-sound were those considered as fermented, heated and sprouted, injured (fermented up to $1 / 4$, broken, hollow, insect damaged), impurities, foreign materials and broken according to the Brazilian Official Grading of corn (1).

The sound and non-sound fractions were ground in a sampling mill (Romer Analytical Sampling Mill) and a subsample was ground in a hammer mill with a 20-mesh screen. Each fraction was homogenized and analyzed in duplicate for aflatoxins $B_{1}$, 
$\mathrm{B}_{2}, \mathrm{G}_{1}$, and $\mathrm{G}_{2}$, by TLC (17), with a detection limit of $1 \mu \mathrm{g} / \mathrm{kg}$. The maximum accepted variation between duplicate results was $30 \%$, otherwise the analysis was repeated. The total contamination of the sample was estimated considering the weight of each fraction and its respective contamination.

\section{Statistical analysis}

The statistical design of the experiment was the completely randomized with 30 repetitions. The contamination levels of the sound and non-sound kernels, considering the average of duplicate analysis, were compared to check if there were statistical differences between the fraction contamination levels by the ANOVA statistic test. For this, the data were transformed to $\log (\mathrm{x}+0.5)$ before its utilization.

Correlations between contamination levels of sound or nonsound with the relative fraction participation in the sample were checked. Correlations between contamination levels of nonsound kernels and the percentage of injured or fermented kernels or impurities present were also checked.

\section{RESULTS AND DISCUSSION}

Grading by quality, showed a higher number of poorer corn types (type 3 and BS, with 10 and 13 samples, respectively) than better corn types, such as types 1 (3 samples) and 2, (4 samples), respectively (Table 2).

It was observed that the contamination levels of non-sound kernels ranged from 23 to $1,365 \mu \mathrm{g} / \mathrm{kg}$ of total aflatoxins (Table 3 ) and were statistically higher than in sound kernels $p<1 \%$ (Tables 4 and 5), that ranged from not detected (ND) to $126 \mu \mathrm{g} /$ $\mathrm{kg}$. The contamination levels of $87 \%$ of the sound fractions were lower than $20 \mu \mathrm{g} / \mathrm{kg}$, the maximum allowed aflatoxin level for corn in Brasil (2). In 13\% of the samples the sound fractions had levels above the tolerance levels but with figures far lower than those of the non-sound kernels. On the other hand all samples of non-sound kernels were above $20 \mu \mathrm{g} / \mathrm{kg}$.

The non-sound fraction weights varied from 8 to $35 \%$ of the total kernels of the evaluated samples (Table 3 ). The correlation between the percentages of the non-sound kernels with the aflatoxin contents was not statically significant $(\mathbf{r}=0.25)$, suggesting that there is not a good correlation between these parameters.

The qualitative data (Table 2) of the samples in the groups: a) injured kernels, b) fermented and sprouted kernels, c) impurities and foreign material, showed correlation values $(\mathbf{r})$ with estimated contamination levels of $0.51,0.52$ and 0.14 , respectively. The statistically significant $\mathbf{r}$ values obtained for injured and fermented kernels, suggests a positive correlation between the percentage of these types of kernels and aflatoxin contamination. However, $\mathbf{r}$ values are low and considering the relatively small number of samples, this observation must be taken carefully and with some restrictions. On the other hand the $\mathbf{r}$ values obtained
Table 2. Moisture content, percentage of defects present and grading by quality of corn samples, according to the Brazilian Official Grading rules (Brasil, 1976).

\begin{tabular}{|c|c|c|c|c|c|}
\hline \multirow[b]{2}{*}{ Sample } & \multirow[b]{2}{*}{$\begin{array}{c}\text { Moisture } \\
\%\end{array}$} & \multicolumn{2}{|c|}{ Injured (\%) } & \multirow{2}{*}{$\begin{array}{l}\text { Extraneous } \\
\text { Materials, } \\
\text { Impurities and } \\
\text { Fragments (\%) }\end{array}$} & \multirow[b]{2}{*}{$\begin{array}{l}\text { Grading } \\
\text { by type }\end{array}$} \\
\hline & & Total & $\begin{array}{l}\text { Fermented } \\
\text { and } \\
\text { Sprouted }\end{array}$ & & \\
\hline 1 & 13.70 & 6.40 & 3.10 & 1.50 & 2 \\
\hline 2 & 11.10 & 7.00 & 2.40 & 3.30 & BS \\
\hline 3 & 13.70 & 8.20 & 3.10 & 2.40 & 3 \\
\hline 4 & 13.40 & 9.50 & 3.40 & 3.00 & 3 \\
\hline 5 & 13.90 & 5.00 & 3.30 & 1.40 & 2 \\
\hline 6 & 12.70 & 9.50 & 6.60 & 3.20 & BS \\
\hline 7 & 13.30 & 7.90 & 2.80 & 3.10 & BS \\
\hline 8 & 12.20 & 7.90 & 3.60 & 4.00 & BS \\
\hline 9 & 14.90 & 11.60 & 3.40 & 3.10 & BS \\
\hline 10 & 12.40 & 8.20 & 2.60 & 1.90 & 2 \\
\hline 11 & 12.60 & 10.00 & 1.90 & 1.50 & 1 \\
\hline 12 & 13.20 & 7.40 & 4.00 & 2.50 & 3 \\
\hline 13 & 13.20 & 10.30 & 3.10 & 3.40 & BS \\
\hline 14 & 13.80 & 8.20 & 3.10 & 3.00 & 3 \\
\hline 15 & 13.40 & 6.80 & 2.30 & 1.30 & 1 \\
\hline 16 & 13.40 & 10.40 & 2.40 & 2.80 & 3 \\
\hline 17 & 13.10 & 6.10 & 2.10 & 3.70 & BS \\
\hline 18 & 12.00 & 11.90 & 3.90 & 3.30 & BS \\
\hline 19 & 12.20 & 11.70 & 3.20 & 4.40 & BS \\
\hline 20 & 11.80 & 7.40 & 1.40 & 2.00 & 2 \\
\hline 21 & 12.80 & 10.00 & 2.20 & 3.50 & BS \\
\hline 22 & 11.70 & 9.2 & 1.00 & 1.30 & 1 \\
\hline 23 & 12.90 & 10.60 & 2.00 & 3.40 & BS \\
\hline 24 & 12.70 & 10.40 & 1.30 & 2.70 & 3 \\
\hline 25 & 12.40 & 20.40 & 4.40 & 3.10 & BS \\
\hline 26 & 12.80 & 9.90 & 0.80 & 2.40 & 3 \\
\hline 27 & 13.60 & 7.20 & 3.90 & 2.70 & 3 \\
\hline 28 & 12.70 & 10.60 & 0.70 & 3.90 & BS \\
\hline 29 & 12.70 & 11.20 & 2.70 & 2.70 & 3 \\
\hline 30 & 12.40 & 17.10 & 7.20 & 2.60 & 3 \\
\hline
\end{tabular}

${ }^{\mathrm{a}}$ Grading of corn by quality in types 1, 2, 3 and BS, according to the percentage of defects observed in the lots (Table 1).

for impurities showed that they did not present correlation with the estimated contamination of the samples.

The participation of the sound kernels in the total weight of the samples was much higher (84\%) than the non-sound ones $(16 \%)$. Even that the sound kernels fraction has presented contamination levels as reported by other authors $(3,15)$, they occurred in low levels with mean value of $15 \mu \mathrm{g} / \mathrm{kg}$ against the mean value of $271 \mu \mathrm{g} / \mathrm{kg}$ for the non-sound kernels (Table 3).

The data obtained in this experiment lead us to assume that the segregation of the non-sound kernels fraction, while in low 
Table 3. Fraction weights, relative participation of fraction weigh in total sample weigh, total aflatoxins contamination $(\mathrm{B} 1+\mathrm{B} 2+\mathrm{G} 1+\mathrm{G} 2)$ of fraction, relative participation of fraction contamination in total sample contamination level and total sample contamination and weight of corn samples.

\begin{tabular}{|c|c|c|c|c|c|c|c|c|c|c|}
\hline \multirow{2}{*}{ Sample } & \multicolumn{4}{|c|}{$\begin{array}{c}\text { Fraction A } \\
\text { Sound kernels }\end{array}$} & \multicolumn{4}{|c|}{$\begin{array}{c}\text { Fraction B } \\
\text { Non-sound kernels }\end{array}$} & \multicolumn{2}{|c|}{ Whole Sample } \\
\hline & $\begin{array}{l}\text { Weight } \\
(\mathrm{g})\end{array}$ & $(\%)^{2}$ & $\begin{array}{l}\text { Cont. }^{1} \\
(\mu \mathrm{g} / \mathrm{kg})\end{array}$ & $(\%)^{3}$ & $\begin{array}{l}\text { Weight } \\
(\mathrm{g})\end{array}$ & $(\%)^{2}$ & $\begin{array}{l}\text { Cont. }^{1} \\
(\mu \mathrm{g} / \mathrm{kg})\end{array}$ & $(\%)^{3}$ & $\begin{array}{l}\text { Weight } \\
(\mathrm{g})\end{array}$ & $\begin{array}{c}\text { Est. Cont. }^{4} \\
(\mu \mathrm{g} / \mathrm{kg})\end{array}$ \\
\hline 1 & 1,471 & 83 & 33 & 47 & 301 & 17 & 183 & 53 & 1,773 & 58 \\
\hline 2 & 1,008 & 86 & N.D. & 0 & 166 & 14 & 23 & 100 & 1,174 & 3 \\
\hline 3 & 1,025 & 85 & 28 & 47 & 176 & 15 & 181 & 53 & 1,201 & 50 \\
\hline 4 & 1,415 & 86 & 19 & 38 & 239 & 14 & 180 & 62 & 1,654 & 42 \\
\hline 5 & 1,194 & 79 & 4 & 4 & 323 & 21 & 351 & 96 & 1,517 & 78 \\
\hline 6 & 1,206 & 82 & 3 & 12 & 263 & 18 & 98 & 88 & 1,468 & 20 \\
\hline 7 & 977 & 77 & N.D. & 0 & 291 & 23 & 346 & 100 & 1,269 & 79 \\
\hline 8 & 1,100 & 81 & 7 & 27 & 259 & 19 & 80 & 73 & 1,359 & 21 \\
\hline 9 & 987 & 78 & 10 & 21 & 285 & 22 & 128 & 79 & 1,272 & 36 \\
\hline 10 & 924 & 82 & 5 & 14 & 208 & 18 & 136 & 86 & 1,132 & 29 \\
\hline 11 & 1,347 & 83 & 4 & 16 & 280 & 17 & 100 & 84 & 1,627 & 20 \\
\hline 12 & 1,087 & 80 & 12 & 3 & 280 & 20 & 1,365 & 97 & 1,366 & 289 \\
\hline 13 & 1,161 & 83 & 3 & 26 & 243 & 17 & 41 & 74 & 1,403 & 10 \\
\hline 14 & 1,222 & 73 & 4 & 5 & 454 & 27 & 186 & 95 & 1,676 & 53 \\
\hline 15 & 1,090 & 84 & 5 & 9 & 207 & 16 & 271 & 91 & 1,296 & 47 \\
\hline 16 & 948 & 80 & 8 & 24 & 231 & 20 & 104 & 76 & 1,180 & 27 \\
\hline 17 & 1,225 & 78 & 5 & 16 & 338 & 22 & 94 & 84 & 1,563 & 24 \\
\hline 18 & 1,172 & 80 & 10 & 7 & 291 & 20 & 538 & 93 & 1,463 & 115 \\
\hline 19 & 1,032 & 68 & 104 & 23 & 480 & 32 & 742 & 77 & 1,512 & 306 \\
\hline 20 & 1,327 & 82 & 6 & 14 & 286 & 18 & 169 & 86 & 1,613 & 35 \\
\hline 21 & 1,190 & 80 & 4 & 5 & 296 & 20 & 277 & 95 & 1,487 & 58 \\
\hline 22 & 1,315 & 84 & 8 & 14 & 242 & 16 & 262 & 86 & 1,557 & 48 \\
\hline 23 & 1,178 & 81 & N.D. & 0 & 285 & 19 & 62 & 100 & 1,463 & 12 \\
\hline 24 & 1,263 & 83 & N.D. & 0 & 254 & 17 & 84 & 100 & 1,517 & 14 \\
\hline 25 & 895 & 63 & 126 & 35 & 535 & 37 & 391 & 65 & 1,430 & 225 \\
\hline 26 & 1,218 & 84 & 4 & 37 & 239 & 16 & 35 & 63 & 1,457 & 9 \\
\hline 27 & 1,101 & 77 & 8 & 18 & 333 & 23 & 120 & 82 & 1,434 & 34 \\
\hline 28 & 1,117 & 79 & 12 & 14 & 291 & 21 & 276 & 86 & 1,408 & 67 \\
\hline 29 & 1,250 & 81 & 3 & 3 & 298 & 19 & 376 & 97 & 1,548 & 75 \\
\hline 30 & 926 & 65 & 14 & 3 & 501 & 35 & 918 & 97 & 1,427 & 331 \\
\hline Mean & 1,146 & 80 & 15 & 16 & 296 & 20 & 271 & 84 & 1,441 & 74 \\
\hline
\end{tabular}

${ }^{1}$ - Aflatoxins contamination level in the fraction $\left(B_{1}+B_{2}+G_{1}+G_{2}\right) ;{ }^{2}$ - Relative participation in weight of the fraction; ${ }^{3}-$ Relative participation of the fraction in the whole sample contamination; ${ }^{4}$ - Estimated contamination.

Table 4. Analysis of the variance.

\begin{tabular}{ccrrrr}
\hline $\begin{array}{c}\text { Variation } \\
\text { factors }\end{array}$ & G.L. & S.Q. & Q.M. & F Value & Prob.>F \\
\hline Type & 1 & 165.0928534 & 165.0928534 & 121.7659 & 0.00001 \\
Residue & 58 & 78.6376526 & 1.3558216 & & \\
\hline Total & 59 & 243.7305060 & & & \\
\hline
\end{tabular}

Overall mean value $=3.519069$; Variation coefficient $=33.088 \%$.
Table 5. Averages of the factor type.

\begin{tabular}{ccccc}
\hline $\begin{array}{c}\text { No. of } \\
\text { Treatments }\end{array}$ & Name & $\begin{array}{c}\text { No. of } \\
\text { Repetitions }\end{array}$ & Means & \multicolumn{1}{c}{$\begin{array}{c}\text { Original } \\
\text { means }\end{array}$} \\
\hline 1 & T1 & 30 & $1.860290 \mathrm{a}$ & 5.925602 \\
2 & $\mathrm{~T} 2$ & 30 & $5.177848 \mathrm{~b}$ & 176.800888 \\
\hline
\end{tabular}

$\mathrm{T} 1$ = Sound kernels; $\mathrm{T} 2$ = Non-sound kernels. 
proportion but much more contaminated, would contribute to reduce the aflatoxin contamination of corn lots bellow the tolerance levels of the Brazilian legislation in $87 \%$ of the samples, notwithstanding the Shotwell et al. $(14,15)$ findings.

From the results the following conclusion could be drawn: a) The sound kernels fraction has presented the lowest contamination levels in all samples; b) The non-sound kernels fraction, even being small in weight, has contributed with $84 \%$ of the estimated contamination of the samples; c) The segregation of the non-sound kernels would favor a reduction in the contamination of the corn lots.

\section{ACKNOWLEDGEMENTS}

The authors wish to thank the Fundação de Amparo à Pesquisa do Estado de São Paulo (1998/06953-8) for the financial support of this research and the corn processing plant for providing the prepared corn samples.

\section{RESUMO}

\section{Distribuição de aflatoxinas em frações de milho segregadas visualmente por defeitos}

A distribuição de aflatoxinas em frações de milho obtidas após segregação visual de defeitos em 30 amostras, sabidamente contaminadas, foi estudada. Cada amostra foi passada em peneiras de crivos redondos de 5,0 mm de diâmetro, classificadas por tipo e então separadas em grãos sadios (regulares) e não sadios (ardidos, avariados, brotados, mofados carunchados, chochos, quebrados, descoloridos e avariados por outras causas) definidos pela Classificação Oficial Brasileira para milho. Os grãos não sadios mostraram contaminação maior em todas as amostras. O nível de contaminação dos grãos não sadios ( $20 \%$ do peso total) variou de 23 a $1365 \mu \mathrm{g} / \mathrm{kg}$ de aflatoxinas $\left(\mathrm{B}_{1}, \mathrm{~B}_{2}, \mathrm{G}_{1}\right.$ e $\left.\mathrm{G}_{2}\right)$ e foram mais elevados que nos grãos sadios $(\mathrm{p}<1 \%)$, que variaram de não detectada (ND) a $125 \mu \mathrm{g} / \mathrm{kg}$ e, em $87 \%$ destas os conteúdos de aflatoxinas foram menores que $20 \mu \mathrm{g} / \mathrm{kg}$. Foram encontrados índices estatisticamente significativos entre as percentagens de grupos de defeitos, tais como, fermentados, imaturos, mofados, ardidos, brotados, total de grãos avariados, com os níveis estimados de contaminação para as frações sadias e não sadias. Concluiu-se que a fração de grãos não sadios, mesmo apresentando pequeno peso, contribuiu com $84 \%$ da contaminação estimada das amostras e que a separação dos grãos não sadios poderá favorecer uma redução na contaminação dos lotes de milho. Os tipos 3 e AP predominaram nas amostras do experimento.

Palavras-chave: aflatoxinas, milho, contaminação, distribuição, separação visual, frações.

\section{REFERENCES}

1. Brasil, Leis, decretos, etc, Ministério da Agricultura, Portaria no. 845, de 08 de novembro de 1976, Diário Oficial da União, Brasília, 19 de novembro de 1976.

2. Brasil, Leis, decretos, etc, Ministério da Agricultura, Portaria no. 183, de 21 de março de 1996, Diário Oficial da União, Brasília, 25 de março de 1996.

3. Brekke, O.L.; Peplinski, A.J.; Griffin Jr., E.L. Cleaning trials for corn containing aflatoxin. Cereal Chemistry, 52: 198-204, 1975.

4. Christensen, C.M.; Kaufmann, H.H. Kernel Storage: the role of the fungi in quality loss. Minneapolis: University of Minnesota Press, 1969. 153p.

5. Fonseca, H.; Nogueira, J.N.; Graner, M.; Oliveira, A.J.; Caruso, J.G.; Boralli, C.; Calori, M.A.; Khatounian, C.A. Natural occurrence of mycotoxins in some Brazilian foods. Part I. V International IUPAC Symposium on Mycotoxins and Phycotoxins, Vienna, Austria. Proceedings, 1982, p.76-79.

6. Fonseca, H.; Nogueira, J.N.; Graner, M.; Oliveira, A.J.; Caruso, J.G.; Boralli, C.; Calori, M.A.; Khatounian, C.A. Natural occurrence of mycotoxins in some Brazilian foods. Part II. World Congress of Food Science and Technology, Dublin, Proceedings, 1983, p.53-4.

7. Gloria E.M.; Fonseca, H.; Souza, I.M. Occurrence of mycotoxins in maize delivered to the food industry in Brasil. Trop. Sci., 37: 107$110,1997$.

8. Lacey, J. Prevention of mould growth and mycotoxin production through control of environmental factors. 'Mycotoxins and Phycotoxins' 1988., Elsevier, Amsterdam, 1989. p.161-169.

9. Lillehoj, E.B.; Kwolek, W.F.; Peterson, R.E.; Shotwell, O.L.; Hesseltine, C.W. Aflatoxin contamination, fluorescence and insect damage in corn infested with Aspergillus flavus before harvest. Cereal Chem., 53: 505, 1976.

10. Rambo, G.D.; Tuite, J.; Caldwell, R.W. Aspergillus flavus and aflatoxin in preharvest corn from Indiana in 1971 and 1972. Cereal Chem., 51: 848-853, 1974.

11. Sabino, M.; Prado, G.; Inomata, E.I.; Pedroso, M.O.; Garcia, R.V. Ocorrência natural de aflatoxinas e zearalenona em milho no Brasil. II Parte. ENCONTRO NACIONAL DE MICOTOXINAS 5., São Paulo, 1988. Resumos. São Paulo: Sociedade Brasileira de Microbiologia, 1988. p.21

12. Santúrio, J.M.; Baldissera, M.A.; Almeida, C.A.A.; Ahmad, S.; Pranke, P.H.L.; Heirichs, C.M. Aflatoxinas, Ocratoxina A e Zearalenona em grãos e rações destinadas ao consumo animal no sul do Brasil. VII Encontro Nacional de Micotoxinas, 1992, São Paulo. Instituto Adolfo Lutz, 1992, v.1, p.12.

13. Santúrio, J.M.; Mallmann, C.A.; Baldissera, M.A.; Almeida, C.A.A.; Pozzobon, M.C.; Schneider, L.G. Qualidade micotoxicológica do milho, sorgo e rações produzidos no Brasil. XXI Congresso Nacional de Milho e Sorgo, Londrina, PR, 1996

14. Shotwell, O.L.; Goulden, M.L.; Hesseltine, C.W. Aflatoxin contamination: association with foreign material and characteristic fluorescence in damaged corn kernels. Cereal Chem., 49: 458-465, 1972.

15. Shotwell, O.; Goulden, M.L.; Hesseltine, C.W. Aflatoxin: distribution in contaminated corn. Cereal Chem, 51: 492-499, 1974.

16. Shotwell, O.L.; Goulden, M.L.; Lillejoj, E.B.; Kwolek, W.F.; Hesseltine, C.W. Aflatoxin occurrence in 1973 corn at harvest. III. Aflatoxin distribution in contaminated, insect-damaged corn. Cereal Chem., 54: 620-626, 1975.

17. Soares, L.M.V.; Rodriguez-Amaya, D.B. Survey of aflatoxins, ochratoxin A, zearalenone and sterigmatocystin in some Brazilian food by using multitoxin thin-layer chromatographic method. J.A.O.A.C., 72: 22-26, 1989. 